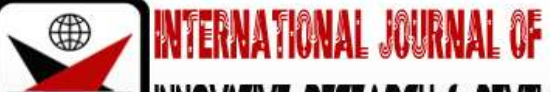

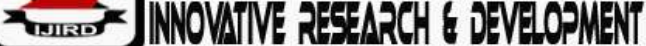

ISSN 2278-0211 (Online)

\section{Impediments to the Realization of International Best Practice in Nigerian Custodial Service}

\author{
Dr. H.O Onyi-Ogelle \\ Lecturer, Nnamdi Azikiwe University Awka, Anambra State, Nigeria \\ Ogboji, Chukwudi Prince
}

Senior Magistrate, High Court of Justice Ebonyi State Judiciary, Abakaliki, Nigeria

\begin{abstract}
:
The network of the criminal justice system is tripodial in nature. The law enforcement agencies kick-start the process and at the end of their investigations releases the suspect into the second stream which is the court. The court takes the defendant(s) through the processes of adjudication and when it finds the defendant not guilty as charged, the defendant is discharged and that ends the chain. However, if on the other hand, the court founds the defendant guilty as charged he/she is taken into the third realm of the criminal justice sector which is the prisons (other terms for a prison include remand centre, custodial service, correctional facility, detention centre, jail/goal, penal colony, penitentiary). Nigerian Custodial Service ideally is established to keep in safe custody of persons legally interred, identify causes of their inherent anti-social behaviours, treat and reform them to become law abiding citizens of a free society, train them towards their rehabilitation and reintegration into the society free from crime after release. However, it is observed with dismay that the service has failed to fulfill its national and international obligations. This is obvious judging from the number of inmates that go in and out of the system, and the rate of recidivism amongst the Nigerian inmates also reveals beyond conjecture that the system has not lived up to its expectation nationally and internationally in treatment of the anti-social behaviour of her inmates despite its avowed claim that it is correctional. It was found that several factors contributed to the inability of the prisons to run on international best practice, and they include among others; Congestion, Practice of Holding charge, Lack of Accommodation Facilities, Poor Funding, Lack of Basic Human Needs, Prisoners' Rights systematically flouted, Jail-Breaks, Recidivism/After Release Care, and Lack of Political Will to implement the provisions of the law and recommendations on reforms. In this wise, it is recommended as follows: deregulation of the management of the prisons to incorporate public-private partnership in the funding and management of the system, utilization of non-custodial sentences, construction of state of art facilities, among others.
\end{abstract}

Keywords: International, correctional, reformation, reintegration, custodial, non-custodial, recidivism

\section{Introduction}

The United Nations Congress on the prevention of crime and the treatment of offenders adopted the Standard Minimum Rules for the Treatment of Prisoners and recommended their approval to the Economic and Social Council, who after extensive deliberation on the said Rules approved it on the 31 ${ }^{\text {st }}$ July, 1957(Resolution 663, 1957). The Rule set out the minimum standard which United Nations accepted as the guide for the enforcement of prison discipline and the general treatment of prisoners. The Council recommended that governments should give favourable consideration to the rules, adopt and apply them in the administration of their penal and correctional institutions. The scope of the Rules was later expanded to cover persons arrested or imprisoned without charge (Resolution, 1993).In December, 2015 the General Assembly adopted its landmark resolution70/175 entitled "United Nations Standard Minimum Rules for the Treatment of Prisoners (the Mandela Rules") after five years revision process. The Mandela Rules comprises 122 items divided among nine parts. Not all are rules, but rather key principles such as institutional equality and the philosophy of confinement (McCrie, 2015).

The Mandela Rules represents the international standard in assessing any nation's correctional institution. Nigeria as a country became a member of the United Nations in 1960 and is obliged to comply with the United Nations Universal Declaration of Human Rights. To this effect, Nigeria has ratified several other international and regional human rights institutions and her human rights obligation extends to those who are in her custodial centres. This is because being deprived of one's liberty does not mean forfeiting other human rights.

The Nigerian Correctional Service, formerly known as Nigerian Prisons Service (NPS) is a government agency of Nigeria which operates the custodial centres. The agency has its headquarters in Abuja, and it is under the supervision of the Ministry of the Interior and the Civil Defense Immigration and Correctional Service. The Service has a total of 240 prison facilities spread across the states of the country with a total inbuilt capacity of 50,153. Ideally the service was 
treat and reform them to become law abiding citizens of a free society, train them towards their rehabilitation and reintegration into the society free from crime after release. However, it is observed with dismay that the system in Nigeria has failed to fulfill its national and international obligations. This is obvious judging from the number of inmates that go in and out of the system, the rate of recidivism amongst the Nigerian inmates also reveals beyond conjecture that the system has not lived up to its expectations nationally and internationally in treatment of the anti-social behaviour of her inmates. In light of the above observations, the poser is- what are the factors that impede the realization of best practice in Nigeria? This will be the centre of our discussion in subsequent subheadings in this work.

\section{Custodial Congestion}

A visit to any custodial centre in Nigeria reveals the poor state of the penal system in Nigeria because of congestion. To talk of prison or custodial congestion is to say that a custodial centre have overshot its inbuilt capacity. Every custodial centre in Nigeria is over-crowded and inmates for example are not only locked up under sub-human conditions, but also kept together without regard to classification according to their offences. It is common sight to see a cell that is meant for four inmates housing more than 50 inmates, living under life threatening situations. The United Nations Minimum Standard Rules for the Treatment of Offenders (SMR) spelt out the borderline condition in which every prisoner should be accommodated thus-

"where sleeping accommodation is in individual cells or rooms, each prisoner shall occupy by night a cell or room by himself or herself. If for special reasons, such as temporary over-crowding, it becomes necessary for the central prison administration to make an exception to this rule, it is not desirable to have two prisoners in a cell or room (Mandela Rules, 2015).

Implicit form the above rule is the specifications of the number of prisoners that should be allowed in a cell. The above situation is clearly in the opposite in Nigeria Prisons. In an article captioned 'Nigerian Prisons are not Correctional Institutions Yet' it was stated as follows:

What you find in the prison set up is that you have accommodation for 200 people instead of that 200, you will find as many as 1000 people. Out of this 1,000 as many as 800 will be those awaiting trial, parked like sardines. Since there is nothing else to do when anyone of them is ill, and because of the overcrowding, the infection spreads rapidly. That is why you find so many of them having tuberculosis. You know tuberculosis ravages a man's body very rapidly (Daily Champion, 1998).

Going by the data released by NBS as at March, 2017 there are over 72,000 inmates with 67\% awaiting trial in Nigerian prisons. As at July, 20018 the number rose to 73,631 with awaiting trial inmates standing at $68 \%$. The summary of inmate population by convict and awaiting trial persons as at $3^{\text {rd }}$ of December, 2018 shows that the total inmate population stood at 75,772 out of which male figure stood at 74,186 and female 1,586; only 24,388 representing $32 \%$ are convicts while the whole of 51,384 representing $68 \%$ are awaiting trial inmates. Available records further show that the service currently holds well over 73,995 inmates spread across the 240 prisons in Nigeria. This is far and above the custodial centres inbuilt capacity and there is no custodial centre that have refused inmates for reasons of congestion in compliance with section 12(8) of the Nigerian Correctional Service Act, 2019 which empowers her to reject inmates once the yard is full.

This is quite alarming and unacceptable. It is appalling to note also that many inmates have spent many years in prison, even more than the number of years they would have spent if convicted, awaiting trial. What can be said simply, in other words, is that congestion in Nigerian prisons negates international standard and the concept of separating inmates based on the nature of their offences, as provided for in the United Nations Standard Minimum Rules for Treatment of Prisons, (Mandela Rules, 2015).

It may be asked at this point what could be the cause of prison congestion in Nigeria? Having seen over the years, the unprecedented upsurge in the number of inmates in the prisons, despite several efforts made at decongesting same, scholars have attributed the cause to delay in criminal trial, police inability to properly investigate matters before charging same to court, budgetary constraint, high population of awaiting trial inmates, the rigidity of the criminal justice system and neglect of the penal sector in Nigeria among others (Ekumankama, 2002 \& Dambazau, 2007).It may be pointed out that overcrowding in Nigerian custodial centres is not in terms of space, but in terms of available facilities. The fact is that the custodial centres were designed and constructed during the colonial era for different purposes, specifically to subjugate those who opposed their system of operation.

\section{Holding Charge}

Holding charge is a situation where criminal charge that is filed against an accused person by the police before a magistrate court that ostensibly has no statutory power to try the offence charged, but however, makes an order remanding the person in prison custody(Okojie, EA\& Enakemere, LE, 2014). As seen in the foregoing the bulk of Nigerian inmates are awaiting trial simply because they were not charged before the appropriate court with jurisdiction to try and grant them bail. The Police adopted this method to circumvent liability for failure to charge in the appropriate court within the constitutionally stipulated time frame. In Enwere v. C.O.P and Shagari \& Ors. $v$ COP the Court of Appeal frowned at the practice and in declaring it unconstitutional held that it was unknown to Nigerian law. However, the apex court shifted ground in Lufadeju \& Anor. v Johnsonfrom the decisions of the Court of Appeal in Enwere v COP and Shagari \& Ors. V. COP when setting aside the judgment of Court of Appeal held that there was no conflict between sections 236 (3) CPA and section 35 of the 1999 Constitution and if anything, the section 236(3) rather complements the provisions of section 32 of the 1979 constitution and is designed to aid the administration of criminal justice in Nigeria. Suffice to say that by judicial precedent, the latter decision of the Supreme Court on the matter became the law. Furthermore, it appears that the 
Administration of Criminal Justice Act has also given a statutory backing to this ugly syndrome of holding charge when in section 293 when it empowered the Magistrate Court to remand a defendant even though it does not have jurisdiction. A community reading of sections 293 -298 particularly section 296 (1)- (7) on time and protocol for remand without charge shows that the longest time is fifty-six (56) days.

It is submitted that the remand order and its time protocol appear to contradict the stated objective of the Act which is speedy dispensation of justice and protection of the rights and interests of the suspect in view of the position of the court in Metuh v FRN. One supposes that ACJA should have entirely abrogated remand proceedings or at most limit it to capital offences rather than leaving it open, obvious of the fact that awaiting trial detainees constitute $70 \%$ of inmates in the custodial centres. Unless the practice of prolonged detention of awaiting trial inmates is abolished completely or reviewed by legislative amendment to comply with the provisions of the Constitution and other international instruments, and resort to other alternatives to pre-trial detention as encouraged in advanced criminal justice systems, the menace of custodial congestion with awaiting trial inmates being the largest may not be abated.

\section{Accommodation Facilities}

It may be said that the literal interpretation of congestion or overcrowding is simply that the facilities and/or accommodation available is short of the number of prisoners using it. That is, the number of inmates admitted to each prison is far and above the required number and facilities provided. When this happens prisoners will be unequally yoked in cells against the International Standards. It is the practice that where dormitories are used, they shall be occupied by prisoners carefully selected as being suitable to associate with one another in those conditions. There shall be regular supervision by night in keeping with the nature of the prison. Rule 13 of the Minimum Standards Rules provides- "All accommodation shall meet all requirements of health, due regard being paid to climatic conditions and particularly to cubic contact of air, minimum floor space, lighting, heating and ventilation."

It was observed that the above is not the case in Nigeria because associated with the problem of congestion and overcrowding is the intractable issue of dilapidated facilities and infrastructure decay in our prisons. There is hardly any ideal prison environment today in Nigeria where one would fond available all complimentary prison facilitates in place. These facilities include but not limited to accommodation, well trained manpower, equipped hospitals and/or medical facilities, sports, and recreational facilities, skills acquisition and educational facilities, sanitary and hygiene facilities, transportation, security and intelligence facilities, clothing facilities, food and feeding, communication and data management facilities, and the like.

The issue of inadequate and/or dilapidated structures can be viewed in several respects; firstly, most of the structures were built before the idea of Nigeria as a country was conceived. For instance, it is believed that the first prison was built in Nigeria in 1872, by the British Government and that was Broad Street Prison(Ekumankama, 2007). Secondly, the service operates sole public funding.

\section{Funding}

Fund is very integral in the smooth running of any organization. The issue of lack of adequate accommodation and dilapidated and/or outdated facilities is because the custodial service is underfunded. It is a fact that the system is an item in the exclusive legislative list which means that the service is a Federal Government concern. It is submitted that the reliance on the concept of sole public funding of Service constitution has resulted indelay in release of funds, poor funding, heavy and avoidable burden on the State (which means the tax payers); dilapidated prison facilities, mismanagement and misappropriation of funds.

In view of the above, it is hereby submitted that Nigeria should quickly amend the constitution by de-regulation of the funding of the prisons. There is an urgent need for the prisons to be re-classified into Federal, State, Local, and private custodial centres similar to what obtains in the United States and some other countries. A tripartite funding by the Federal, State and Local Governments cum pubic private partnership in the funding of the service is a key to an effective decongestion of prison, lack of funds, and dilapidated structures.

\section{Basic Human Needs}

Under the Mandela Rule, every prisoner shall be provided by the prison administration at the usual hours with food of nutritional value adequate for health and strength, of wholesome quality and well prepared and served. The case in Nigeria appears to be the different. While the custodial service headquarters provides every prison with daily budget for each inmate, to cover the cost of food. Portions of food allotted to inmates are quite small and not well prepared. This is because according to inmates, the quantity and quality was highly poor and unacceptable though it was three times a day (Omaka, 2005). In the words of an inmate visited by Amnesty International-'It is not good for health. Even the rice is not good- it is stone rice'. The food we eat is not the food that a human being will eat. Even a dog cannot eat the food' (Amnesty International). Obvious of this predicament the prison officers often allow inmates' relatives to bring food to them upon payment of an undisclosed sum of money. The fact remains that with the total number of inmates in the custodial centre, it is actually nearly impossible to provide the prisoners with wholesome meal, both in quantity and quality.

On the issue of bed space and bedding we had already established in the foregoing that the custodial centres are congested. The effect therefore is on bed space and bedding, contrary to the International Minimum Standard Rule that every prisoner shall, in accordance with local or national standards, be provided with separate bed and with separate and sufficient bedding which shall be clean when issued, kept in good order and changed often enough to ensure its cleanliness(SM Rules). Nigerian inmates sleep on bare floor, and when bed is provided, it is removed because there is no space in the cell. As a result of rampant overcrowding; inmates routinely share beds or sleep on the floor. According to one 
of the inmates 'sometimes when you sleep you wake up with your back paining you.' To further buttress the predicament of the custodial inmates in this respect, a guard in Enugu prisons offered this explanation for the paucity of bedding thusThe supplies come from Abuja. They only supply the number of the prison capacity. Consequently, in prisons that incarcerate double their official capacity, half of the inmates do not have beds. For instance, in Enugu prison, the cells for inmates awaiting trial have no beds at all; as a result, up to 100 men and children per cell were sleeping on the bare floor.

The position in Enugu prisons is virtually the same throughout the country. In the International scene untried prisoners are expected to sleep singly in separate rooms, except the climatic atmosphere depicts otherwise. This is because they are deemed innocent and should be so treated until the contrary is proved. More so, there should not be any need for them to be separated only for the purposes of not been given bed as seen in Enugu prison.

On personal hygiene and sanitation, the incident of over population has crippled every effort of the custodial officers to maintain clean environment. This ranges from the fact that the sanitary facilities in all the prisons require immediate repair, due to over use. In some cells up to 100 inmates share a single toilet, which is often little more than a hole in the ground. In some other places, buckets are used as toilets. The fact is that the incident of congestion coupled with inadequate sanitary facilities makes it virtually impossible to keep the cells clean. An inmate interviewed by Amnesty International retorted-'Everywhere, all this place, its smelling. The toilet is full, for water, we used to get one cup, we can't get water all the time. Even at times you see the water is very dirty'. The standard everywhere is that the sanitary installations shall be adequate to enable every prisoner to comply with the needs of nature when necessary and in a clean and decent manner. To this end all parts of a prison regularly used by prisoners shall be properly maintained and kept scrupulously clean at all times. Provision of water and toilet articles is a key to personal hygiene.

On health care services, it is observed that the provision of health care for prisoner is a State responsibility. Thus, prisoners should enjoy the same standards of health care that are available in the community, and should have access to necessary health care services free of charge without discrimination on the grounds of their legal status. The health care service shall consist of an interdisciplinary team with sufficient qualified personnel acting in full clinical independence and shall encompass sufficient expertise to psychology and psychiatry and the service of a qualified dentist shall be available to every prisoner. The case is different in Nigeria prisons; this is because many custodial centres do not have hospitals, and those that have clinic, lack medical professionals and drugs to treat the patients.Despite the poor health-facilities in the prisons, it has been noted that there are inmates with life threatening ailments in the various prisons. Such ailment may include tuberculosis, HIV/AIDs, cancer, skin problems, malaria, mental illness, diabetes, infections, asthma or lice amongst others. This is obviously the result of appalling sanitary conditions in the cells, making it very easy for inmates to infect each other. The truth is that the custodial authorities simply cannot guarantee cleanliness inside the cells and this is a violation of the prisoner's right to health. Article 25(1) of the Universal Declaration of Human Rights guarantees the right to a standard of living adequate for the health.

It is submitted, that it is the non-availability of necessary medical facilities in our custodial centres that warrant the granting of application for bail on medical reasons by some court of law. The controversial case of Bamiyi $v$ Stateset a centre stage for such applications, which to everyone's knowledge is only available to the rich. Lack of medical facilities further proves that the custodial service in Nigeria is not 'working'. A scenario was painted of a middle-aged man arrested of robbing a bank of $\$ 1$ in the United States of America. Funny enough rather than running away he went outside the bank and sat down on the entrance, meaning that he really wanted to be arrested. People became curious of why he had to do that; it was unraveled by security agents that the man had emergency health issues and his health insurance had already expired. Fully aware, that prison inmates enjoy free healthcare, he desperately needed to get into the prison so he could benefit from free medical care, even if it means giving up his freedom. That's a 'working' prisons system. It is saying the obvious that the Nigerian custodial service with its present status cannot guarantee the health rights of its inmates.

\section{Prisoners Rights}

An inmate is one who is deprived of his liberty. In a broader sense, it means one who is kept against his will in confinement or custody in a prison, penitentiary, jail or other correctional institutions, as a result of conviction of crime or awaiting trial. From the above definition two categories of prisoner emerged-first is those that have been tried and convicted and the second are those that are yet untried but whose liberty is restricted. The latter class, are called the awaiting trial inmates, and constitutionally presumed innocent until the contrary is proved. The question therefore is whether a prisoner of whatsoever class has a right obvious of the fact that it was breach of the law of the land that landed him/her in custodial centre? The answer to the above poser is in affirmative, a prisoner has right both before and after conviction. The rights of prisoners primarily geared towards enhancing their welfare. It seeks to protect them from arbitrary treatment from prison officials whether convicted or merely accused, deprivation of liberty does not mean deprivation of humanity for the prisoner. Except expressly taken away or by necessary implication, a convicted prisoner in spite of his imprisonment, retains all civil rights. Lord Justice Shaw of the English Court of Appeal in Rv. Board of Visitors of Hull prisons ex parte St. Germain \& others held that-

Prisoners are subjected to a special regimen and have a special status. Nonetheless, they are not entirely denuded of all fundamental rights and liberties which are inherent in our constitution...Thus, despite the deprivation of his general liberty, a prisoner remains invested with residuary rights appertaining to the nature of his incarceration

At home in Nigeria, Uwaifo J.C.A (as he then was) in Peter Nemi \& Ors v Attorney-General of Lagos State disagreed with the submission of the leaned state counsel that a condemned convict has no right under any legislative or judicial provision in Nigeria to enforce his fundamental rights and as such as good as dead. 
It is material to note that Nigerian inmates do not enjoy most of the rights mentioned above, obvious of the incidence of congestion and overcrowding. This is aptly captured by the report of the Amnesty International when it said that Nigeria prisoners' rights are systematically flouted. It was revealed in the foregoing that against the international standard, most of the Nigerian custodial centres lack clear-cut classification, cells congested, inadequate accommodation (bed space and beddings), poor diet, poor medical care and recreational facilities, poor sanitation and personal hygiene, to mention but the above. All these bother on the welfare of the inmates and when their welfare rights are trampled upon, it always led to crisis in the custodial centre.

\section{Jail-Breaks}

In recent times, jail breaks in Nigerian Custodial Service have become recurrent phenomena. This poses security concerns and serious threats not only to the service authority, but also to the government and the people. Jail break itself, is an unlawful act under Nigerian law, even in the international community. Jail break is the unlawful escape of a prisoner from the prisons. That is, a situation where the inmates force their way out of custody. It can also be by attack on the Nigerian Prisons Service by terrorist or hoodlums. For instance, on 15 th February, 2012 Boko Haram attacked Koto-Karfi prisons in Kogi State, releasing about 119 awaiting trials persons (including Boko Haram suspects). It was observed that jail break in Nigeria between 2009 to 2019 has resulted to the escape of over 3000 prisoners spread across Nigerian Custodial.

The all-important question that should be asked is what are the remote and/or immediate causes of custodial riots and jail breaks in Nigeria obvious of the fact that the core mandate of the Nigerian custodial service is to promote public protection by providing assistance for offenders in their reformation and rehabilitation under safe, secure and humane conditions, in accordance with universally accepted standard and to facilitate their social reintegration into the society. It sadly noted that inmates' care and social conditions are the overwhelming reasons why inmates are likely to riot in Nigerian custodial centres. In a survey done by John Omale 0 , he uncovered the variables that result to prison break/riots in Nigeria to include- overcrowding in cells, trafficking by staff, and inmates, poor feeding/nutrition, lack of supervision/poor management, deprivation of certain perceived rights and privileges, inadequate staffing of prisons, careless transfers of staff and prisoners, poor communication/relationship between staff and inmates/poor grievance policy inadequate prison clothing, beds and beddings, inadequate medical/health services, non-production and reproduction of awaiting trial persons in court, staff brutality of inmates, external security threats, corruption/favoritism, lack of water supply, poor funding, inadequate security features such as CCTV, Motion sensors, high wall made up of barbed wire and sometimes electric fencing of the wall and the like.

A case of the substandard living conditions of the inmate which resulted in riot was seen in the Kuje prisons riot of 28 $8^{\text {th }}$ March 2007, where two inmates died and others injured. Narrating the remote and immediate cause of the riot, an inmate stated that the riot was provoked by shortages of food and water. A more recent one was the 2016 jail break in Abakaliki prisons in Ebonyi State where one prison guard was believed to have been killed in the early hours of Thursday $(19 / 08 / 2016)$, when the inmates of the prisons rioted over the poor meals served on them by the custodial officers and attempted to escape from the facility.

\section{Recidivism/After Release Care}

Recidivism means a relapse into crime and criminal lifestyle or activities by an offender who was once or more times been processed through the penal system (Otu, 2015). The prisons system in Nigeria is witnessing an increase in people relapsing into crime and criminality after release. It is obvious that it affects the practicality and feasibility of any attempt to introduce rehabilitation programmes in the system. It is observed that with the custodial centres overcrowded, it does not adequately prepare inmates for obtaining jobs to facilitate reintegration into the mainstream of the society after release from custody. Indeed, ex-offenders upon release enter a hostile world where they are ill-prepared in their background or skills to enter normative employment and/or receive social acceptance from citizenry. Added to these difficulties in economic survival and social interactions tend to push ex-offenders back toward prison, where they are accepted by fellow inmates and receive free food, shelter, clothing and medical treatment. This is an affront to the international best practice, rule 98 of the International Minimum Standards for treatment of prisoners provides that '...so far as possible the work provided shall be such as will maintain or increase the prisoner's ability to earn an honest living after release'. By rule 99, the prison organization and methods of work is to be cultured in a way that it shall resemble as closely as possible those of similar work outside of prisons, so as to prepare prisoners for the conditions of normal occupational life.

In contrast to the above requirements, what is operational in the custodial according to Tenibiaje (2010) is ...cottage industries train the inmates in industrial production, furniture making, soap making, toilet roll, manufacturing aluminum pots and metal work fabrication. Can this help inmates to be self-sustaining after being discharged? This type would not prepare them for productive employment and cannot reduce recidivism. This type of training does not offer the skills needed in today's job market and does not provide for the needs of prison inmates. The prison inmates need skills such as literacy and vocational skills that are functional and productive.

He further maintained that there is not counseling geared towards preparing inmate for his release and for productive employment which should reflect: Education in prison that increase literacy; Vocational education with 'live work' projects and apprenticeship certificate; Six-Twelve months educational programme which leads to certain certificate after completion; Correctional education programme can be molted in prisons to improve on education of inmates; Post-Secondary education in prison is another positive direction towards productive employment; Vocational training job related to current market with expanded apprenticeship programme (Tenibiaje, 2010). Lacks of after release 
care among things have been singled out as one of the causes of recidivism in the Nigerian custodial centres. It is believed that proper and effective transformation and reintegration would reduce recidivism in Nigerian prisons (Otu, 2015).

\section{Political Will}

It is obvious from the foregoing that the Nigerian custodial service are characterized by overcrowding, poor staff morale, inadequate funding, poor clean environment, corruption and dehumanizing treatment; with no designed and wellarticulated administrative, reformative, and rehabilitative programmes aimed at inculcating discipline, respect for law and order, regard for dignity of honest labour and reintegration. This has remained so, and will continue to be the state of the system until the policy makers stop playing politics with custodial service reform because of the gains they make therefrom. Several working groups and committees have been established in this regards and recommendations made but the government has always failed to implement those reforms. Part 46 sections $470-475$ of The Administration of Criminal Justice Act, 2015 established Administration of Criminal Justice Monitoring Committee and about five years after no committee has been set up to perform the function stated in section 470 one of which is to deal with pre-trial detention and congestion. Furthermore, Part 44 of the Actprovided for non-custodial alternatives and up till moment facilities to foster the provisions of sections 453 - 467 are not yet in place. Whatmore, few months back the National Assembly amended the prison Act changing the name to Nigerian Correctional Service and further provided for Custodial and Noncustodial services. Though very laudable but it is sad that no step has been taken to establish the Custodial Centres Visitors board and National Committee on Non- Custodial Measures in order to perform the functions in sections 22 and 38 of the Actrespectively. Unfortunately, that has been the fate of the system from inception, majority of the recommendation of the committee on custodial reform has always been swept under carpet. Some of those recommendations have been translated to law yet to no avail. The recommendations and the laws appear to be more of words and paper, which have left the real situation in Nigerian custodial centres unattended. Inmates awaiting trial especially those who cannot afford legal support wait years for their trial to take place; prisons remain overcrowded; prison authorities do not appear to receive the funds that have been allocated to improving conditions of the system.

\section{Conclusion}

Judging from the forgoing, it is registered without conjecture that the Nigerian Custodial Service is far behind best practice. Enuku (2001) and Parkinson (1983)summarized the indices of custodial best practices to include; short detention without trial, humane principles for the treatment of offenders, education/skill acquisition programmes. For inmates, placement of inmates in prisons nearer to friends and relations, visitation hours without supervision of visitors by authority, regularity of visits to inmates, particularly on Saturdays and Sundays and holidays, defined number of inmates in a cell of a particular measurement, provision of modern sanitary infrastructures and lavatory, provision of charity legal aid to inmates who cannot afford the high cost of the judicial process and staff welfare.

\section{Recommendations}

In view of our findings above we recommend as follows:

- Deregulation of the management of the prisons to incorporate public-private partnership in the funding and management of the system.

- Reclassification of the service into Federal, State, Local and Private Custodial Centres

- Utilization of non-custodial sentences and restorative justice measures

- Construction of state of art facilities.

- Implementations of the provisions of Administration of Criminal Justice Act, 2015 and Nigerian Correctional Service Act, 2019.

\section{References}

i. Dambazau, AB.(2007) Criminology and Criminal Justice, $2^{\text {nd }}$ edn, Ibadan, Spectrum Books Ltd, Publishers.

ii. Ekumankama UD. (2002) Criminology and Penology, Aba: Star Paper Mill Limited, publishers

iii. Enuku, EU. (2001), Humanizing the Nigerian Prison through Literacy Education: Echoes from Afar. JCE vol. 52, Issue 1. Available at http:/www.nwlines.org/correctional-educational/articles/Nigerian-prison-enuku.pdf.

iv. Eze MC. (2010), Institutional Reforms and the Development of Nigeria Prisons Service, 1999 - 20007, Journal of African Studies and Development Vol. 2(5).

v. McCrie, Robert, and Annabelle Clemont, “The Mandela Rules: Will They Impact American Corrections?” Corrections Today, vol. 77, no. 5, Sept. 2015, pp.44-48.

EBSCOhost,mctproxy.mnpals.net/login?url=http://search.ebscohost.com/login.aspx?direct=true \&db=aph\&AN=11 0150866\&site=ehost-live. Accessed on 17th day of August, 2019 @ about 02:15pm.

vi. Okojie EA. \& Enakemere LE. (2014), The Illegality of practice of Holding charge under the Nigerian Criminal Justice System, African Journal of Law and Criminology, Volume 4 No. 1.

vii. Omaka, CA. (2014) Decongesting Prisons in Nigeria: The EBSU Law Clinic Model, International Journal of Clinical Legal Education, 20(11).

viii. Omale DJO (2013), Riots/Jail Breaks in Nigeria Prisons: An Aetiological Study, Canadian Social Science, $9(1)$.

ix. Otu, MS. (2015) Analysis of Causes and Effects of Recidivism in the Nigerian Prison System, International Journal of Development and Management Review, Vol. 10, No. 1.

x. Parkinson, E (1983) Educating Adults in Prison, Studies in the Education of Adults. 
xi. Unini Chioma, 'Revisiting Nigeria- British Prisoners Transfer Agreement' available at https: thenigerialawyer.com/revisiting-nigeria-british-prisoners-transfer-agreement/ accessed on 18/02/2019 @ about 10:40am

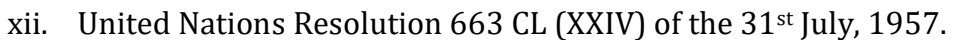

xiii. United Nations Resolution 1993 (LX) of 12th day of May, 1976 which amended the United Nations Standard Minimum Rules for the Treatment of Prisoners 1957 by addition of Rule 95.

xiv. United Nations Minimum Standard Rules for the Treatment of Prisoners, (Mandela Rule) 2015.

xv. Administration of Criminal Justice Act, 2015.

xvi. Amnesty International Nigeria; Prisoners' Rights Systematically Flouted (London: Amnesty International Publications, 2008).

xvii. Black's Law Dictionary, Sixth Centennial Edition, (1891-1991).

xviii. Constitution of the Federal Republic of Nigeria, 2009.

xix. Nigerian Correctional Service Act, 2019

xx. Disday news of Friday, $20^{\text {th }}$ August, 2016.

xxi. News24 of 20/08/2016.

xxii. Vanguard News of $20^{\text {th }}$ August, 2016.

xxiii. Bamiyi v State(2001) 4 SCNJ 10.

xxiv. Enwere v. C.O.P(1993) 6 NWLR (Pt. 436) 320 pp.335

xxv. Lufadeju \& Anor. v Johnson(2009) 8 ACLR 190 @ 213.

xxvi. Metuh v FRN (2018)3 NWLR (Pt.1605) 1 paras C-A, pp:82-83.

xxvii. Oshinaga v. C.O.P (2004) 17 NWLR (Pt. 901) 1.

xxviii. Peter Nemi \& Ors v Attorney-General of Lagos State(1996) 6NWLR (Pl 452) p. 42.

xxix. Raymond v Honey (1982) IALL E.R 757 at 759.

xxx. R v. Board of Visitors of Hull prisons ex parte St. Germain \& others(1979) 1 Q.B 425.

xxxi. Shagari \& Ors. v COP (2005) All FWLR (Pt. 262) 451 pp 469

xxxii. http://databod.com/infograhics/nigeria-prison-statistics-incarceration-rates-states-gender-religion-genderothers. accessed on 04/09/2018 @ about 8:36am.

xxxiii. The Nigeria Prisons Statistics as at 16 $16^{\text {th }}$ July, 2018 http://www.prisons.gov.ng/about/statistical-info.php accessed on04/09/2018@ about 08:51am.

xxxiv. Summary of Inmates population as at 16 th July,2018 available @ http://databod.com/infograhics/nigeria-prisonstatistics-incarceration-rates-states-gender-religion-gender-others. accessed on 04/09/2018 @ about 8:36am.

xxxv. www.prisons.gov.ng>statistics accessed on 06/03/2019 @ about 11:58am.

xxxvi. Prisonsreformtrust.org. Uk (11/08/2015) 4:30pm. tackling prison overcrowding: building more prison? sentence fewer offenders? books. google.com 28/8/2007 retrieved from en.m wikipedia.org 11/08/2015.

xxxvii. Nigerian prison and its lacuna, @ http://archives.ngrguardiannews.com/index.php/compulife/203- youthspeak/185745-nigerian-prison-and-its-lacuna published 06 November, 2014 accessed on 07/02/2015. 